\title{
DEVELOPING TEACHING MATERIALS USING 5E MODEL OF INSTRUCTION TO INCREASE STUDENTS' HIGHER ORDER THINKING SKILLS
}

\author{
Lilik Mutrofin'), Mohamad Nur'), Leny Yuanita ${ }^{3)}$ \\ 1) Science Education Study Program, Postgraduate Program, State University of Surabaya \\ 2), 3) State University of Surabaya \\ E-mail: elka.pkr05@gmail.com
}

\begin{abstract}
Abstrak: Penelitian ini bertujuan untuk mengembangkan bahan ajar menggunakan model pembelajaran 5E untuk meningkatkan keterampilan berfikir tingkat tinggi siswa serta mendeskripsikan kelayakan bahan ajar tersebut. Bahan ajar dalam penelitian ini dikembangkan dengan menggunakan model 4-D yang diusulkan oleh Thiagarajan, Semmel dan Semmel. Subyek dalam penelitian ini adalah bahan ajar yang telah dikembangkan dan diuji cobakan kepada mahasiswa tahun pertama angkatan 2014 di Jurusan Biologi, Universitas Muhamadiyah Surabaya (UMS) dan di Jurusan Kimia, Universitas Negeri Surabaya (UNESA). Desain penelitian yang digunakan ketika uji coba bahan ajar adalah one-group pretest and posttest dengan replikasi sebanyak tiga kali. Selain itu, untuk setiap replikasi menggunakan sekitar 15 mahasiswa. Data dikumpulkan menggunakan penilaian ahli, observasi, tes, dan kuesioner serta dianalisis secara kuantitatif dan deskriptif kualitatif. Penemuan penelitian ini menunjukkan bahwa bahan ajar yang dikembangkan memenuhi kriteria kelayakan, yaitu valid menurut pendapat para ahli, praktis dan efektif ketika diuji cobakan di dalam kelas.
\end{abstract}

Kata Kunci: keterampilan berfikir tingkat tinggi, model pembelajaran 5E.

\begin{abstract}
The aims of this study were to develop teaching materials using 5E model of instruction to increase students' higher order thinking skills and to describe their feasibility. The teaching materials (i.e. lesson plan, student worksheet, and higher order thinking skills test) were developed using 4-D model that was proposed by Thiagarajan, Semmel and Semmel. The subject of this study were the developed teaching materials that were tried out to undergraduate students of Biology Department, University of Muhamadiyah Surabaya (UMS) and undergraduate students of Chemistry Department, State University of Surabaya (UNESA). The developmental testing was designed using the one-group pretest and posttest design with three times replication. Additionally, each replication used about 15 undergraduate students. Data were collected using experts' appraisal, observation, test, and questionnaire and analyzed quantitatively and descriptive qualitatively. The findings of this study indicated that the developed teaching materials were feasible. They were valid according to experts' appraisal, and they were practice and effective to be implemented in the classroom
\end{abstract}

Keywords: higher order thinking skills, 5E model of instruction.

\section{INTRODUCTION}

Education has played important roles to create human resources with certain qualification for each generation. Such qualification usually needed by the generation in order to survive in the society where they live in. In the $21^{\text {st }}$ century today, the qualification that should be owned by human resources is shifted from simple cognitive skills into more complex cognitive skills. This fact is supported by data that provided by Murnane as cited in Jerald (2009:5). According to him, the demand of human resources is changed from routine cognitive into expert thinking during 19691998.

Jerald (2009) stated that some experts argue that the $21^{\text {st }}$ skills that should be owned by the human resources has closed relationship to Bloom's Taxonomy that usually used by teachers to plan their lesson in the classroom. Krathwohl (2002) explained that Bloom's Taxonomy has six categories, namely, Knowledge, Comprehension, Application, Analysis, Synthesis, and Evaluation which is later revised become Remember, Understand, Apply, Analyze, Evaluate and Create. In addition, Anderson and Krathwohl as cited in Brookhart (2010:5) argue that 'the top ends' of revised Bloom's Taxonomy, namely, analyze, evaluate, and create is classified as Higher Order Thinking Skills (HOTS).

Situation and condition that is explained above has been considered by curriculum maker in Indonesia. Therefore, in 2007, the Center of Curriculum in Indonesia (Pusat Kurikulum) released an academic document which is intended to evaluate the curriculum 
of science. It is said that the curriculum of education in Indonesia, particularly science, should be improved so that the qualification of students fulfill the acquisition that is needed by the development of society (Puskur, 2007). Puskur (2007:24) recommended that the learning process in the classroom should pay more attention to teach and assess the aspect of higher order thinking skills.

In order to make the recommendation which is related to support students' higher order thinking skills, the Center of Curriculum supported the recommendation with the data gain from the international forum that is held by OECD (Organization for Economic Co-operation and Development), namely, PISA (Program for International Assessment). According to Puskur (2007:2), the rank of Indonesian students in science proficiency is $38^{\text {th }}$ from 41 countries in 2000 and in the rank of $38^{\text {th }}$ from 40 countries in 2003. Rustaman as cited in Puskur (2007:21) explained that the data above shows that the proficiency of Indonesian students still in remembering scientific knowledge based on simple evidence. In the case of Bloom's Revised Taxonomy, the term of remembering located in lower order thinking.

Although the Center of Curriculum in Indonesia has recommended in fostering activities that enhancing higher order thinking skills in the classroom in 2007, the result of PISA 2012 is not far. The rank of Indonesian students in science proficiency is $64^{\text {th }}$ from $65^{\text {th }}$ countries in 2012 (OECD, 2014). Additionally, low achievers reached the value of $75.7 \%$. This condition is supported by the result of my preliminary test on higher order thinking skills (particularly in the topic of reaction rate) at Biology Department, University of Muhamadiyah Surabaya (UMS) and at Chemistry Department, State University of Surabaya. The result of my preliminary test that I took from the first year student of 2014 (who have not learned the topic of reaction rate previously at any undergraduate course) shows that the students' average score of HOTS test in reaction rate topic is 4.33 . This value could be interpreted as low score. In other words, higher order thinking skills of undergraduate students at Biology Department, University of Muhamadiyah Surabaya (UMS) and at Chemistry Department, State University of Surabaya (UNESA) still need to be supported. Therefore, activities and also teaching material that support students' higher order thinking skills should be developed. Additionally, Chingos and Whitehurst (2012) explained that instructional materials (teaching materials) have large effects on student learning. For this reason, I am interested in developing teaching material in order to support students' higher order thinking skills.
Related to the case of enhancing students' higher order thinking skills, the Curriculum of Education in Australia (www.curriculumpress.edu.au) explained that inquiry learning will be able to help the students fostering their thinking process. In this case, inquiry learning asked them to be critical, creative and reflective thinkers. In the term of critical thinking, the Curriculum of Education in Australia (www.curriculumpress.edu.au) argued that inquiry learning involved all level of Bloom's Taxonomy particularly higher order thinking level. This statement is supported by Friedel, Irani, Rudd, Gallo, Eckhardt and Ricketts (2008). According to them, inquiry basedlearning is significantly able to foster students' higher order thinking skills. Therefore, in this research, the teaching material will be developed by using inquirybased learning in order to support students' higher order thinking skills.

According to the explanation above, inquiry-based learning is strongly able to enhance students' higher order thinking skills. Soomro, Qaisrani, Rawat and Mughal (2010) reported that one of methods that are able to create inquiry-based learning is learning cycle/5E model (Engagement, Exploration, Explanation, Elaboration and Evaluation). It is supported by Acisli, Yalcin \& Turgut (2011) who saying that $5 \mathrm{E}$ model is an effective teaching method for inquiry-based learning. They reported that by using $5 \mathrm{E}$ model (learning cycle), students are able to discover and learn knowledge in their course on their own by questioning, searching, and using primary knowledge. Furthermore, Bybee (2009) argued that 5E model of instruction is able to enhance the development of $21^{\text {st }}$ century skills, that is higher-order thinking skills. Additionally, Bybee et al. (2006) argued that 5E model of instruction is able to be used in wide range of topic in science including rate of reaction.

The main research question in this research is "How is the feasibility of teaching materials that are developed using 5E model of instruction to increases students' higher order thinking skills?" Nieveen (1999:127) explained that the term of feasibility consist of three aspects i.e. validity, practicality and effectiveness of the developed teaching material. In this research, the term of practicality will be answered by collecting data related to the completion of lesson plan, students' activities, and obstacles that will be found during instructional process in the classroom. Additionally, the term of effectiveness will be answered by collecting data related to the result of HOTS test and students' responses.

This research at least has two significances. For one thing, higher order thinking skills are well-known needed by young generation to solve their problems in their daily life (Aksela, 2005). Therefore, this research 
will provide one reference to support this idea. Second, this research provides one alternative in developing teaching materials that will enhance students' higher order thinking skills using 5E model of instruction. Therefore, if the result of this research seems to be effective to help the teachers constructing students' knowledge and supporting students' higher order thinking skills, then it could be used in the classroom.

\section{METHODOLOGY OF RESEARCH}

The type of this research was developmental research because it was aimed to develop teaching materials and then, they were going to be implemented in the classroom to confirm their practicality and their effectiveness. The subject of this research was the developed teaching materials. They have been implemented to 29 undergraduate students year 2014 at Biology Department, University of Muhamadiyah Surabaya (UMS) and 20 undergraduate students year 2014 at Chemistry Department, State University of Surabaya (UNESA). The teaching materials were developed using 4-D model that was proposed by Thiagarajan, Semmel and Semmel (1974). This 4-D model consists of four stages, namely, define, design, develop and disseminate. For the purpose of this research, the development of teaching material has been limited until the third stage, i.e. develop stage. Therefore, disseminate (the fourth stage of 4-D model) has been eliminated because the developed teaching materials will not be spread.

This second developmental testing was delivered using the one-group pretest and posttest design with three times replication. According to Nieveen (1990) a replication is like a cycle process, therefore, it could be used to revise the developed teaching material if needed by considering the result of each replication. Data in this research were gathered using at least four techniques i.e. (1) expert appraisal, (2) observation, (3) test, and (4) questionnaire. The data in this research were collected using at least six instruments i.e. (1) expert appraisal sheet, (2) observation sheet of lesson plan completion, (3) observation sheet of students' activities, (4) observation sheet of obstacles, (5) HOTS test, and (6) questionnaire. Additionally, the collected data were analyzed quantitatively and descriptive qualitatively.

\section{RESULTS AND DISCUSSION}

The whole results of the second developmental testing confirm that the developed teaching materials were feasible. As suggested by Nieveen (1999), the term of feasible in this study consists of three aspects i.e. validity, practicality and effectiveness. Firstly, the validity of the developed teaching materials was got from the appraisal that was collected from the experts.
According to the experts, the whole teaching materials were developed validly. The average score that was given by the experts for lesson plan, student worksheet and HOTS test was $3.57,3.25$, and 3.70 respectively. It means that the lesson plan and the student worksheet have been developed well and the HOTS test has been valid to measure students' higher order thinking skills. Secondly, the practicality of the developed teaching materials was confirmed by the data that were collected from the second developmental testing. There were at least three data that were able to explain the practicality of the developed teaching material i.e. (1) the data related to the completion of lesson plan, (2) the data related to students' activities during instructional processes, and (3) the data related to the obstacle that found during the instructional process. The whole those three data confirmed that the developed teaching materials were practice to be implemented in the classroom. Thirdly, the effectiveness of the developed teaching materials was also confirmed by the data that were collected from the second developmental testing. There were at least two data that were able to confirm the effectiveness of the developed teaching material i.e. (1) the data related to the HOTS test, and (2) the data related to the responses that were provided by the students. The whole those two data confirmed that the developed teaching materials were effective to be implemented in the classroom.

There were at least four crucial aspects that need to be considered in this study. Firstly, the teaching material that was developed using $5 \mathrm{E}$ model of instruction could stimulate students' thinking and enhance students' higher order thinking skills (i.e. analyzing, evaluating, and creating). This finding was supported by the additional comment that was provided by the students. Other data that support this finding i.e. the result of higher order thinking skills test. This data show that there was significant improvement on the score of students during pretest and posttest. The average gain score of the students during the second developmental testing shows that the students get medium-g-level. This finding was relevant by the study that was conducted by Friedel, Irani, Rudd, Gallo, Eckhardt and Ricketts (2008). According to them inquiry-based learning was significantly able to enhance students' higher order thinking skills. Additionally, Bybee (2009) argued that 5E model of instruction was able to support the development of $21^{\text {st }}$ century skills i.e. higher-order thinking skills. Secondly, the time that was arranged in 5E model of instruction should be planned carefully. This study has found that although the time has been designed well, however, an extra time still needs to be added to finish learning process. This finding could be happened because $5 \mathrm{E}$ model of instruction and the developed 
student worksheet that was constructed using $5 \mathrm{E}$ model of instruction were recent for the students. Moreover, the additional comment that was provided by the students also confirms this finding. However, the management of time could be improved gradually when the learning process proceed as the students become familiar with $5 \mathrm{E}$ model of instruction and the developed students worksheet. This finding was relevant with some studies in this field. Jackson and Boboc (2008) argued that time was one of crucial problem that usually faced by the teachers who were using inquirybased learning in their classes. Lamanna (2010) also found that time was usually become a problem for classes that was using inquiry-based learning. Jackson and Boboc (2010) suggested some ways to overcome time challenge when the lecturer using inquiry-based learning such as giving clear directions and guidelines to make the students best use of their time; guiding students through directions before and during the instructional activities; and posting directions for students as they come into the classroom engages students in the day's activities as soon as they enter the classroom. Thirdly, the developed teaching material could be implemented well in the classroom. However, if this teaching material will be used to teach students outside chemistry department, a little modification should be made especially on the motivation part. Moreover, this motivation part should be modified based on the background of students (following the interest of students). This finding was supported by additional comment that was provided by the student from Biology Department. Lastly, this study was designed using $5 \mathrm{E}$ model of instruction in the whole meeting (i.e. four meetings). Additionally, the learning was designed in which the students work in a small team every meeting. Additional comment that was provided by the students revealed that some of the students feel bored if the same model of instruction was used for several meeting continuously. It could not be denied that the member of the classroom come from different backgrounds. Therefore, in order to accommodate the students' interest, Alberta (2010) suggested the using of differentiated instruction. Alberta (2010:4) explained that there are some ways that could be done in order to realize differentiated instruction in the classroom such as providing multiple pathways to learning and taking a flexible and reflective approach.

\section{CLOSING}

\section{Conclusion}

The findings of this study indicated that the developed teaching materials using 5E model of instruction were valid according to experts' appraisal; they were practice to be implemented in the classroom by considering three aspects, i.e. (1) the developed lesson plan could be implemented well in the classroom, (2) the students were highly engaged in 5E model of instruction environment, and (3) although there were some obstacles found during instructional processes, yet they could be minimized; and they were effective to be implemented in the classroom by considering two aspects, i.e. (1) the higher order thinking skills showed significant improvement during pretest and posttest, and (2) the students provided positive responses on the implementation of the developed teaching material.

\section{Suggestions}

Based on the findings of this study, there were at least four suggestions that could be proposed for the next study, i.e.:

1. 5E model of instruction was considered to be effective to help students to construct their own knowledge and to build their own understanding so that the learning process could be meaningful. Additionally, guidance could be provided for students who faced difficulties during the learning process.

2. In order to apply $5 \mathrm{E}$ model of instruction in the classroom, the arrangement of time should be designed carefully considering the experiences of students.

3. If the developed teaching material will be used to students at other department (not chemistry student), some modifications need to be done. The most important part that needs to be modified i.e. motivation part. It should be linked to the interest of students.

4. In order to accommodate the variety of students' background, differentiated instruction could be chosen as an alternative in the classroom.

\section{REFERENCES}

Acisli, S., Yalcin, S. A., \& Turgut, U. 2011. Effect of $5 \mathrm{E}$ learning model on students' academic achievement in movement and forces issues. Journal of Procedia Social and behavioral Sciences, pg. 2459-2462. Retrieved from www.sciencedirect.com.

Aksela, M. 2005. Supporting Meaningful Chemistry Learning and Higher-Order Thinking through Computer-Assisted Inquiry: A design approach. Helsinki: Faculty of science. Retrieved from http://ethesis.helsinki.fi.

Alberta. 2010. Making a difference: Meeting diverse learning needs with differentiated instruction. Canada: Alberta. Retrieved from www.education.alberta.ca. 
Brookhart, S. M. 2010. How to assess higher-order thinking skills in your classroom. Beauregard St.: ASCD.

Bybee, R. W. 2009. The BSCS 5E instructional model and $21^{\text {st }}$ century skills. A commission paper prepared for a workshop on exploring the intersection of science education and the development of $21^{\text {st }}$ century skills.

Bybee, R. W., Taylor, J.A., Gardner, A., Scotter, P.V., Powell, J.C., Westbrook, A., \& Landes, N. 2006. The BSCS 5E Instructional model: origin, effectiveness, and Application. Retrieved from www.bscs.org.

Chingos, M. M., \& Whitehurst, G. J. 2012. Choosing blindly instructional materials, teacher effectiveness and the common core. Retrieved from www.brooking.edu.

Friedel, C., Irani, T., Rudd, R., Gallo, M., Eckhardt, E., \& Ricketts, J. 2008. Overtly Teaching Critical Thinking and Inquiry- Based Learning: A Comparison of Two Undergraduate Biotechnology Classes. Journal of Education Agricultural, Volume 49, Number 1, p. 72-84. DOI: 10.5032/jae.2008.01072.

Jackson, D.K., \& Boboc, M. 2008. Facilitating inquirybased science classroom. Retrieved from www.academic.csuohio.edu.

Jerald, C. D. 2009. Defining a $21^{\text {st }}$ century education. Retrieved from www.centerforpubliceducation.org on August 2 $2^{\text {nd }}, 2012$.

Krathwohl, D.R. 2002. A revision of Bloom's taxonomy: an overview. Journal of Theory into
Practice, volume 41, number 4. Ohio: The Ohio State University. Retrieved from www.unco.edu.tax bloom.

Lamanna, S.M. 2010. Inquiry-based learning and student retention. Education and Human Development Master's Theses. Retrieved from www.digitalcommons.brockport.edu.

Nieveen, N. 1999. Design Approaches and Tools in Education and Training, J. Akker et al (Eds): Formative evaluation in educational design research. Netherlands: Kluwer Academic Publisher.

Nieveen, N. 1999. Design Approaches and Tools in Education and Training, J. Akker et al (Eds): Prototyping to reach product quality. Netherlands: Kluwer Academic Publisher.

OECD. 2014. Pisa 2012 result in focus: what 15-yearsolds know and what they can do with what they know. Retrieved at January 25 $5^{\text {th }}, 2015$.

Puskur. 2007. Naskah Akademik: Kajian Kebijakan Kurikulum Mata pelajaran IPA. Jakarta: Balitbang Depdiknas.

Soomro, A. Q., Qaisrani, M. N., Rawat, K. J., \& Mughal, S. H. 2010. Teaching physics through learning cycle model: An experimental study. Journal of Educational Research, Volume 13.

Thiagarajan, S., Semmel, S. D., \& Semmel, M. L. 1974. Instructional development for training teachers of exceptional children. Bloomington: Indiana University.

www.curriculumpress.edu.au. 